\title{
ALLAH MENDENGAR SERUAN DAN TEMPAT BERLINDUNG: Penelitian puitis Mazmur 5
}

\author{
Armand Barus*
}

\begin{abstract}
Abstrak: Pembacaan Mazmur 5 dengan menggunakan metode penelitian puitis (poetic criticism) menyingkapkan pesan berbeda dengan metode pemberian makna teks oleh para penafsir mazmur ratapan (lament psalm) sebelumnya. Metode penelitian puitis memperhatikan keluhan pemazmur, perasaan pemazmur yang disebabkan keluhannya, pengertiannya dan pengakuannya tentang Allah di dalam keluhannya dan perubahan suasana teks (mood) dalam menguak pesan mazmur ratapan. Penerapan penelitian puitis terhadap Mazmur 5 menghasilkan pesan tentang Allah yang mendengar seruan dan tempat berlindung. Pengenalan pemazmur akan Allah yang mendengar seruan dan tempat berlindung mengubah ratapan (lament) pemazmur menjadi pujian.
\end{abstract}

Abstract: Reading psalm 5 by using poetic criticism reveals differing message with the methods used by lament psalms' interpreters when reading psalm 5 . The method of poetic criticism takes into consideration the lamentation of the psalmist, the feelings resulted from the lament, the psalmist understanding dan knowledge of God in the midst of psalmist lamentation dan the mood of the text in examining lament psalms. Applying poetic criticism to psalm 5 produces a message concerning God who hears and protects. The personal knowledge of the psalmist of God who hears dan protects radically changes the lament into joy.

Kata-kata Kunci: Mazmur ratapan, penelitian puitis, keluhan, perasaan, Allah, perubahan suasana teks (mood), takut akan Allah, ibadah.

* Penulis adalah dosen Biblika di Sekolah Tinggi Teologi Amanat Agung. Penulis dapat dihubungi melalui email: armand_barus@sttaa.ac.id. 


\section{Pendahuluan}

Mazmur 5 adalah suatu ratapan pribadi $^{1}$ seperti terlihat melalui penggunaan bentuk orang pertama tunggal yang mendominasi teks bacaan dan kata benda hăḡî́̄ĝ̀ (ay. 2) yang lebih tepat diterjemahkan sebagai 'ratapan' ketimbang 'keluh kesah' (LAI:TB) serta kesejajaran tiga kola ratapan 'berilah', 'indahkanlah', dan 'perhatikanlah' (ay. 2-3). Pertanyaan pokok yang muncul adalah apa, sebagai suatu ratapan pribadi, pesan sentral Mazmur 5 ?

Artur Weiser mengajukan usulan penggunaan Mazmur 5 di Bait Allah ketika pelaksanaan persembahan korban pagi hari seperti

1. Robert Davidson, The Vitality of Worship: A Commentary on the Book of Psalms (Grand Rapids, Michigan: William B. Eerdmans, 1998), 25; Artur Weiser, The Psalms: A Commentary, The Old Testament Library (Philadelphia: Westminster, 1962), 123; A.A. Anderson, The Book of Psalms: Psalms 1-72, vol. 1, New Century Bible Commentary (Grand Rapids, Michigan: William B. Eerdmans, 1972), 81; Peter C. Craigie, Psalms 1-50, Word Biblical Commentary 19 (Dallas: Word Books, 1983), 85. Craigie dan Mowinckel menyatakan Mazmur 5 sebagai "protective psalm". Bruce K. Waltke, James M. Houston, dan Erika Moore, The Psalms as Christian Lament: A Historical Commentary (Grand Rapids, Michigan: William B. Eerdmans, 2014), 25, berdasarkan penelitian bentuk (form criticism) mazmur ratapan memiliki motif tipikal: (1) address with introductory petitions to be heard; (2) confidence with lament; (3) petitions with lament; (4) petitions with praise. Craig C. Broyles, "Psalms Concerning the Liturgies of Temple Entry," dalam The Book of Psalms: Composition and Reception, ed. oleh Peter W. Flint dan Patrick D. Miller, Jr (Leiden: Brill, 2005), 284, menolak pandangan umumnya penafsir Mazmur 5 sebagai ratapan pribadi. Broyles menyimpulkan Mazmur 5 termasuk juga Mazmur 26, 28, 36 dan 52 "should not be categorized as laments for individuals to use in special emergencies; they belong to the regular liturgies that all worshipers would invoke, probably during pilgrimage festivals" (284-285). 
dinyatakan dalam ayat $4 .^{2}$ Dalam ibadah itu, menurut Artur Weiser, pemazmur memohon Allah "to pass judgment on the machi-nations and intrigues those wicked men (ay. 11) and hoping for his protection (ay. 12-13)". ${ }^{3}$ Pemazmur memohon Allah untuk menghukum orang fasik bukan karena ia sudah tidak tahan lagi menghadapi kejahatan mereka tetapi karena mereka "have reached the limit of their wickedness". ${ }^{4}$ Benarkah pesan Mazmur 5 adalah tentang permohonan pemazmur kepada Allah untuk menghukum perbuatan dan perkataan jahat orang fasik? Dari arah berbeda Barth-Frommel dan Pareira menyatakan "Inti doa permohonan Mazmur 5 ini terdapat pada ayat 9. Pemazmur memohon supaya Tuhan menyatakan karya keselamatan-Nya kepadanya". ${ }^{5}$ Umumnya penafsir melihat pemazmur dalam Mazmur 5 sedang mengalami ancaman dari musuh. John Goldingay merumuskan pesan sentral Mazmur 5 dengan ungkapan "How is a person to react when maligned by people using deceit and fraud in a life-threatening way?". ${ }^{6}$ Lagi, pemazmur dalam Mazmur 5 "under threat from enemies who are bringing false accusations against him or are publicly slandering him". ${ }^{7}$ Benarkah semua ini adalah pesan sentral

2. Weiser, Psalms, 123, 125.

3. Weiser, Psalms, 124.

4. Weiser, Psalms, 128.

5. Marie-Claire Barth-Frommel dan B. A. Pareira, Kitab Mazmur 172: Pembimbing dan Tafsirannya (Jakarta: BPK Gunung Mulia, 2012), 153.

6. John Goldingay, Psalms 1-41, vol. 1, Baker Commentary on the Old Testament Wisdom and Psalms (Grand Rapids: Baker Academic, 2006), 127.

7. Davidson, Vitality of Worship, 25; Anderson, Psalms 1-72, 1: 81. 
Mazmur 5? Benarkah pemazmur sedang menghadapi ancaman musuh?

Survey penafsiran tersebut di atas, meski ringkas, sudah cukup memperlihatkan keragaman pesan mazmur 5 yang dihasilkan para penafsir. Jelas terlihat bahwa para penafsir belum mencapai konsensus terhadap pesan sentral mazmur 5. Keadaan ini segera menimbulkan pertanyaan, apa sesungguhnya pesan sentral Mazmur $5 ?^{8}$

Mazmur 5 bila ditelaah dengan menggunakan penelitian puitis $^{9}$ akan menghasilkan pesan berbeda dengan hasil penafsiran sebelumnya. Penelitian puitis memperhitungkan keluhan pemazmur, perasaan pemazmur yang timbul sebagai akibat keluhannya, pengenalan pemazmur akan Allah di dalam dan melalui penderitaannya, perubahan suasana teks (mood) sebagai cerminan ratapan dan pujian ketika pemazmur mengalami penderitaan. Keluhan dan perasaan pemazmur dalam mazmur ratapan adalah dua unsur yang sering diabaikan penafsir ketika menguak makna

8. Tentang tafsiran Jerome (342-420) terhadap Mazmur 5 lihat Waltke, Houston, dan Moore, Psalms as Christian Lament, 21-23. Jerome mendasarkan tafsirannya pada kata klēronomousēs (LXX) pada judul Mazmur 5. Kata klēronomousēs ditafsirkannya sebagai gereja. Berdasarkan ini Jerome memahami Mazmur 5 sebagai mazmur polemik melawan bidatbidat seperti Arianisme, Montanisme dan Pelagianisme. Jerome menulis "the church from its very beginning was resolute for the truth of God. No arrogant sinner can stand in the presence of God. It is only the church that can fight against heretics with the hatred with which God himself would destroy his enemies, for "You destroy those who tell lies (ay. 7)"" (22).

9. Tentang penelitian puitis lihat Armand Barus, Mengenal Tuhan Melalui Penderitaan (Jakarta: Scripture Union Indonesia, 2016). 
mazmur-mazmur ratapan. Telaah saksama yang dilakukan terhadap Mazmur 5 dengan penelitian puitis mengungkapkan pesan tentang Allah, bukan tentang pemazmur seperti yang selama ini dipahami. Pesan sentral ini kemudian dibawa secara reflektif ke dalam konteks Indonesia. Kontekstualisasi teks merupakan keharusan dalam proses pemberian makna teks.

Pembacaan terhadap mazmur ratapan 5 menyingkapkan kehadiran seteru menyebabkan pemazmur melantunkan ratapannya kepada Allah. Apa yang dilakukan seteru terhadap pemazmur? Siapakah seteru pemazmur? Keberadaan seteru menimbulkan dua bentuk perasaan dalam diri pemazmur yaitu takut dan sukacita. Apa artinya takut dan sukacita? Apakah dua bentuk perasaan ini merupakan suatu tahapan atau bersamaan terjadinya? Selanjutnya di dalam interaksi kausal aspek keluhan dan dimensi perasaan, bagaimana pemahaman dan pengenalan akan Allah menolong pemazmur untuk melihat dan meletakkan pergumulan eksternal dan internal dalam perspektif yang seharusnya? Bagaimana pergerakan perubahan suasana teks (mood) pemazmur ketika menjalani pergumulan rohaninya?

\section{Keluhan}

Seteru (ay. 9)

Pemazmur menyingkapkan masalah dan pergumulan hidupnya disebabkan kehadiran seteru (šôrərāy) dalam hidupnya. Apa yang diperbuat seteru terhadap pemazmur? Pembacaan teliti menyatakan 
bahwa tidak ada perbuatan atau perkataan seteru yang menyakitkan diri secara fisik dan hati pemazmur. Craigie tepat mengamati "Whether the evil persons specified in these verses are the actual enemies of the psalmist is uncertain. They are presented simply as the archetype of those persons banned from God's presence" ${ }^{10}$ Tetapi mengapa mereka menjadi seteru pemazmur? Alasannya diungkapkan dalam ayat 5-7 seperti terlihat dalam kesejajaran berikut:

Sebab Engkau bukanlah Allah yang berkenan kepada kefasikan;

orang jahat

Pembual

Engkau membenci semua orang yang

Engkau membinasakan orang-orang yang TUHAN jijik melihat
pada-Mu. di depan mata-Mu;

Allah tidak berkenan kepada kefasikan, Allah membenci pelaku kejahatan, Allah membinasakan pembohong dan Allah jijik melihat penumpah darah dan penipu. Dengan perkataan lain, manusia yang dibenci Allah menjadi seteru pemazmur. Perbuatan jahat yang tidak disukai Allah adalah juga kebencian pemazmur. Mereka menjadi seteru pemazmur oleh karena mereka memberontak kepada Allah. Mereka tidak menyerang pemazmur secara verbal dan fisik.

Lebih jauh pemazmur menggambarkan para seterunya, seperti tampak dalam kesejajaran tersebut di atas, sebagai orang fasik, orang

10. Craigie, Psalms 1-50, 87. 
jahat, pembual, pelaku kejahatan, pembohong, penumpah darah dan penipu. Mereka mengerjakan pekerjaan-pekerjaan yang menjadi kebencian bagi Allah.

Karakteristik utama seteru pemazmur tampak jelas melalui cara mereka berkata-kata. Tidak jauh berbeda Craigie menyatakan kefasikan seteru pemazmur "are characterized here entirely in terms of their speech in a manner which illustrates forcefully the potential evil of the tongue". ${ }^{11}$ Seteru pemazmur adalah pembual, penipu, tidak jujur, batin busuk, kerongkongan seperti kubur ternganga, lidah merayu-rayu. Pemazmur menyoroti perkataan mereka seperti terlihat dalam kesejajaran ayat 10.

perkataan mereka

batin mereka

kerongkongan mereka

lidah mereka tidak ada yang jujur, penuh kebusukan, seperti kubur ternganga, merayu-rayu.

Batin seteru pemazmur yakni hati mereka penuh kebusukan. Kebusukan menunjuk kepada "destructive forces that bring ruin. The destructive forces, always plural in this use, are usually evil speech, which in many instances is also associated with lies and treachery". ${ }^{12}$ Perkataan seteru pemazmur dilukiskannya sebagai kubur ternganga yang siap menerima mayat untuk dikubur di dalamnya. Kerongkongan seperti kubur ternganga menggambarkan perkataan

11. Craigie, Psalms 1-50, 1.

12. Waltke, Houston, dan Moore, Psalms as Christian Lament, 38. 
yang menyebabkan kematian. Menurut Barth-Frommel dan Pareira bahasa gambaran (imagery) 'seperti kubur ternganga' merujuk kepada perkataan "yang selalu siap mengancam hidup sesamanya dan menelannya sebagai mangsanya". ${ }^{13}$ Perkataan orang fasik adalah perkataan mematikan sesamanya.

Lidah itu membunuh. Pemazmur menggambarkan ketajaman lidah seperti 'pisau cukur yang diasah' (Mzm. 52:4), atau 'pedang terhunus' (Mzm. 55:22), atau 'pedang tajam' (Mzm. 57:5), atau 'pedang atau panah' (Mzm. 64:4). Senjata-senjata dalam perang kuno seperti pedang dan panah digunakan pemazmur untuk melukiskan betapa perkataan manusia mampu membunuh sesamanya dengan efektif.

Di samping bersalah dalam perkataan seperti berkata bohong dan menipu, mereka juga melakukan beragam perbuatan jahat seperti melakukan kejahatan (ay. 6), penumpah darah (ay. 7). Pemberontakan seteru pemazmur terhadap Allah diwujudkan terutama dalam bentuk perkataan juga perbuatan. Kaitan perkataan dan perbuatan terlihat jelas, misalnya, dalam Mazmur 141:3-4, 9 di mana pemazmur memohon Allah menjaganya dari berkata dan berbuat jahat. John Goldingay memberi komentar terhadap Mazmur 141:3-4 sebagai berikut "Behind the mouth is the heart, the inner thinking that expresses itself in words. In front are the deeds that put the words in action; "having dealings" ('untuk melakukan' pada ayat 4) makes the point with some emphasis. Specifically the dealings are 
things that involve evil and faithlessness, as in the parallel 140: 2, 5, with people who do harm."14 Melarang orang fasik berkata dan berbuat jahat berada di luar kendali pemazmur. Yang dapat dilakukan pemazmur adalah memohon agar Allah memeliharanya hatinya yang dipandang sebagai sumber perkataan dan perbuatan. Ini jugalah yang terjadi sebenarnya pada pemazmur dalam Mazmur 5.

Apakah perkataan dan perbuatan orang fasik telah mengancam bahkan membuat hidup pemazmur menderita? Tidak terlihat pernyataan eksplisit yang menyatakannya dalam teks bacaan mazmur 5. Mereka menjadi seteru pemazmur bukan karena pemazmur telah menjadi salah seorang korban perbuatan dan perkataan jahatnya. Mereka memusuhi Allah dan, akibatnya, keadaan ini menyebabkan mereka menjadi seteru pemazmur. Ringkasnya, manusia yang memusuhi Allah adalah seteru pemazmur.

Keberadaan seteru di sekitar hidup pemazmur menimbulkan dua bentuk perasaan seperti terungkap dalama mazmur 5 .

\section{Perasaan}

Takut akan Allah (ay. 8)

Perasaan takut yang timbul dalam diri pemazmur bukan disebabkan oleh perbuatan dan perkataan jahat orang fasik. Keberadaan dan kehadiran orang fasik di sekeliling hidup pemazmur

14. John Goldingay, Psalms 90-150, vol. 3, Baker Commentary on the Old Testament Wisdom and Psalms (Grand Rapids, Michigan: Baker Academic, 2008), 656. 
menimbulkan perasaan takut kepada Allah. Bagaimana penjelasannya? Perasaan takut pemazmur muncul ketika pemazmur berada di hadirat Allah saat beribadah sujud menyembah-Nya di Bait Allah di Yerusalem. Pemazmur berkata 'aku akan masuk ke dalam rumah-Mu, sujud menyembah ke arah bait-Mu yang kudus dengan takut akan Engkau' (ay. 8). Dalam ibadah di rumah Allah ${ }^{15}$ pemazmur berhadapan dengan kekudusan Allah melalui pemberian korban persembahan. Allah membenci dosa dan tidak membiarkan orang berdosa mendekatinya dengan caranya sendiri. Allah telah menetapkan ritual dan ibadah bagaimana manusia berada di hadiratNya. ${ }^{16}$ Keadaan ini sudah menimbulkan perasaan takut akan Allah dalam diri pemazmur ketika berhadapan dengan kekudusan Allah. Tidak hanya itu. Pemazmur juga mengalami perasaan takut akan Allah melalui penyingkapan diri Allah. Bagaimana penjelasannya? Sebelum menjelaskannya terlebih dahulu dirumuskan arti takut akan Allah.

Apa arti takut akan Allah? Ungkapan takut akan Allah (yir'at yhwh ('ädönäy)) telah diteliti dalam skala monograf oleh beberapa ahli seperti Joachim Becker (1965) dan Louis Derousseaux (1970).

15. Tentang rumah Allah lihat Othmar Keel, The Symbolism of the Biblical World: Ancient Near Eastern Iconography and the Book of Psalms (Winona Lake: Eisenbrauns, 1997), 151-163.

16 Lihat Robin Routledge, Old Testament Theology: A Thematic Approach (Downers Grove: IVP Academic, 2008); Walther Eichrodt, Theology of the Old Testament, vol. 1 (Philadelphia: Westminster, 1961), 98177; William Dyrness, Themes in Old Testament Theology (Downers Grove: IVP Press, 1979), 143-159. 
Becker mengategorikan takut akan Allah ke dalam tiga arti: pertama, moral (takut akan Allah adalah perilaku yang benar); kedua, ibadah (takut akan Allah adalah bentuk ibadah yang benar); ketiga, hukum (takut akan Allah berarti menaati hukum). ${ }^{17}$ Dalam kategori moral takut akan Allah, seperti dijelaskan dan diuraikan literatur hikmat Yahudi, dipahami para ahli dalam tiga pengertian: pertama, takut akan Allah mendahului hikmat (Gerhard von Rad); kedua, takut akan Allah mendahului hikmat dan membawanya kepada takut akan Allah yang lebih dalam (Michael Fox); ketiga, takut Allah tidak lain adalah hikmat (Henry Blocher). ${ }^{18}$

Namun apa sesungguhnya arti takut akan Allah dalam ayat 8 ? Apa pengertian takut akan Allah adalah seperti penjelasan para ahli tersebut di atas? Kesejajaran kola ayat 8 memperlihatkan pengertian bahwa takut akan Allah harus dipahami dalam konteks ibadah di Bait Allah di Yerusalem. Konteks ibadah ditegaskan juga dengan ungkapan 'pada waktu pagi aku mengatur persembahan bagi-Mu' (ay. 4). Bait Allah di Yerusalem adalah "a symbol of God's heavenly dwelling and presence; the worshiper sought ultimately to enter not simply a building, but a living presence". ${ }^{19}$ Ringkasnya, berada di bait Allah tidak lain berada di hadirat Allah. Pemazmur menyadari kehadirannya di dalam ibadah bukan karena kesalehannya tetapi

17. Dikutip Henri Blocher, "The fear of the Lord as the "principle" of wisdom," Tyndale Bulletin 28 (1977): 7.

18. Diskusi lihat Zoltàn Schwab, "Is Fear of the LORD the Source of Wisdom or Vice Versa?," Vetus Testamentum 63, no. 4 (Oktober 2013): 653654.

19. Craigie, Psalms 1-50, 87. 
semata-mata karena kasih setia ${ }^{20}$ Allah yang besar. Ibadah pemazmur bukan merupakan hasil usahanya atau ritual mendekati Allah atau kesalehannya, akan tetapi semata-mata disebabkan kasih setia Allah kepadanya.

aku, berkat kasih setia-Mu yang besar, aku akan masuk ke dalam rumah-Mu, sujud menyembah ke arah bait-Mu yang kudus dengan takut akan Engkau.

Berdasarkan kesejajaran kola tersebut di atas, takut akan Allah berada dalam kategori ibadah. Perasaan takut akan Allah dalam diri pemazmur muncul ketika beribadah kepada Allah "is not simply a matter of a naked feeling of terror, putting one to flight, but of an oscillation between repulsion and attraction, between mysterium tremendum and fascinans". ${ }^{21}$ Tepatnya perasaan takut Allah ini digambarkan sebagai perasaan kagum dan hormat (awe, reverence) (Latin: mysterium tremens). ${ }^{22}$ Meski demikian kita tidak setuju pendapat Eichrodt yang menyatakan takut akan Allah berarti "to keep his commandments, or to walk in his ways". ${ }^{23}$ Juga kita tidak setuju dengan pandangan William Dyrness tentang takut akan Allah sebagai "a way of life based on a sober estimate of God's presence and care" ${ }^{24}$ Ketika pemazmur beribadah kepada Allah di bait suci di

20. Tentang kasih setia lihat Barus, Mengenal Tuhan, 115-117.

21. Walther Eichrodt, Theology of the Old Testament, vol. 2 (Philadelphia: Westminster, 1967), 269.

22. Eichrodt, Theology of the Old Testament, 2: 269.

23. Eichrodt, Theology of the Old Testament, 2: 299.

24. Dyrness, Themes in Old Testament Theology, 162. 
Yerusalem di situlah muncul perasaan takut akan Allah. Keberadaan pemazmur di hadirat Allah menimbulkan rasa takut. Ibadah kepada Allah itulah yang menyebabkan lahirnya perasaan takut akan Allah. Takut akan Allah merupakan "the result of the divine self-revelation and, in consequence of that, the free gift of his grace" ${ }^{25}$ Namun tidak tepat juga bila dikatakan bahwa ibadah adalah bentuk konkret takut akan Allah atau takut akan Allah diwujudkan dalam ibadah. Pemazmur datang sujud menyembah Allah di Yerusalem dan dalam ibadah itu lahirlah perasaan takut akan Allah yakni perasaan kagum dan hormat kepada Allah. Perasaan kagum dan hormat timbul oleh karena Allah menyingkapkan siapa diri-Nya kepada pemazmur (theophany). Penyingkapan akan kekudusan Allah. Motif penyataan Allah diteguhkan juga dengan ungkapan 'mengasihi nama-Mu' (ay. 12). Yahweh adalah nama Allah yang dinyatakan kepada Musa (Kel. 3:14). Nama Allah sebagai teofani berfungsi sebagai "the guarantee of the divine presence" dan "the representative of the transcendent God". ${ }^{26}$ Asosiasi nama Yahweh dan bait suci Yerusalem (UI. 12:5) menyatakan "the particular presence of God in that place". ${ }^{27}$ Pemazmur sebagai orang yang mengasihi nama Yahweh menunjuk kepada penyingkapan kehadiran Allah kepadanya di rumah Allah yang menjadi tempat kesukaannya. Kehadiran Allah dimanifestasikan melalui kemuliaan-Nya (Kel. 24:16-17). Bait Allah di Yerusalem

25. Weiser, Psalms, 127.

26. Eichrodt, Theology of the Old Testament, 2: 41.

27. Eichrodt, Theology of the Old Testament, 2: 41. 
merupakan simbol kehadiran Allah di antara umat. Yehezkiel melihat kembalinya kemuliaan Allah ke bait-Nya (Yeh. 43:4).

Sukacita (ay. 12)

Tidak hanya perasaan takut, pemazmur juga memiliki perasaan sukacita di dalam dan melalui pergumulannya. Sukacita pemazmur merupakan sukacita yang bersifat ontologis (being joyful) bukan sekadar sukacita yang ekspresif (doing joyful). Sukacita yang muncul ketika pemazmur beribadah di bait Allah dan berjumpa dengan Allah saat ibadah bersama umat.

Menurut Weiser perasaan sukacita pemazmur muncul oleh karena hukuman telah dijatuhkan terhadap orang fasik yang ditandai dengan berakhirnya "the pressure of persecution"28 terhadap pemazmur. Pendapat Weiser tidak sesuai dengan ayat 12. Pemazmur bersukacita oleh karena ia berlindung pada Allah bukan karena terhentinya penganiayaan. Dalam garis searah Craigie juga sependapat bahwa "The ground for rejoicing is not the impending destruction of the wicked persons, but rather the spontaneous result which is experienced by all those 'who take refuge' in God". ${ }^{29}$ Kata kerja berlindung ( rujukan berada di bait Allah di Yerusalem (Mzm. 61:5). Berlindung pada Tuhan berarti berada di bait Allah. Pemazmur bersama-sama

28. Weiser, Psalms, 128; Barth-Frommel dan Pareira, Mazmur 1-72, 153.

29. Craigie, Psalms 1-50, 88. 
dengan umat Tuhan beribadah sujud menyembah Allah menciptakan keadaan sukacita. Ungkapan 'semua orang berlindung' menunjuk kepada persekutuan umat yang beribadah menyembah Allah di baitNya. Persekutuan inilah yang membuat pemazmur bersukacita. Ini keberadaan sukacita (being joyful).

Jadi, ibadah di bait Allah di Yerusalem bersama-sama dengan umat Allah lainnya melahirkan dua bentuk perasaan dalam diri pemazmur yakni takut akan Allah dan bersukacita. Perasaan takut akan Allah timbul karena penyataan diri Allah kepada pemazmur sedang perasaan sukacita lahir oleh karena persekutuan pemazmur dengan jemaat dalam ibadah menyembah Allah. Pemazmur menyadari bahwa orang fasik tidak akan tahan berdiri di hadirat Allah. Jika pemazmur tahan berdiri di hadirat Allah itu semata-mata oleh karena kasih setia-Nya. ${ }^{30}$

Pemazmur, seperti disebutkan di atas, mengalami perasaanperasaan takut akan Allah dan sukacita saat beribadah di bait-Nya. Allah seperti apa yang menyatakan diri kepada pemazmur dalam ibadah tersebut?

30. Diskusi kasih setia (hesed) lihat Sung-Hun Lee, "Lament and the Joy of Salvation in the Lament Psalms," dalam The Book of Psalms: Composition and Reception, ed. oleh Peter W. Flint dan Patrick D. Miller, Jr, Supplements to Vetus Testamentum XCIX (Leiden: Brill, 2005), 226-239. Menurur Lee kasih setia (hesed) memiliki aspek bersyarat dan tanpa syarat. Aspek bersyarat kasih setia menunjuk kepada "a reciprocal act towards the other party in a relationship, since one's hesed is contingent upon the behaviour of the other". Aspek tanpa syarat hesed menunjuk kepada tindakan Allah yang membuat "a unilaterally continuous commitment to providing his hesed to the other party, whether to Israel or to individuals". 


\section{Allah}

Rajaku dan Allahku (ay. 3)

Pemazmur menyapa Allah adalah Rajanya. Relasi personal pemazmur dan Allah terungkap melalui pengakuan "Rajaku dan Allahku". Sebagai Raja Allah mengatur dan memerintah hidup pemazmur dengan hukum dan peraturan. Allah tidak hanya menjadi Raja atas seluruh umat manusia tetapi juga Raja atas diri pemazmur secara pribadi. Penggunaan sapaan Raja juga mengungkapkan keyakinan pemazmur pemerintahan Allah atas seluruh alam semesta dan sejarah manusia. Tuhan adalah Raja oleh karena Tuhan menciptakan alam semesta dan manusia (Mzm. 95:3-5). Bagi pemazmur berdoa dalam ibadah berarti menghadap dan berbicara kepada Raja. Seperti layaknya rakyat menghadap raja, persiapan pribadi perlu dan harus dilakukan. Apa isi percakapan dengan raja? Tindakan pertama yang dilakukan pemazmur dalam memulai hariharinya adalah dengan memberi korban persembahan. Istilah 'waktu pagi' pada ayat 4 menunjuk kepada "the coming of sunrise, from the time when the stars that presage the new day are still visible (Ayb. 38:7) and people and things are scarcely visible (Kej. 29:25; Rut. 3:14; 1Raj. 3:21) to the breaking of the sun over the horizon (Hak. 9:33; 2Sam. 23:4; 2Raj. 3:22)". ${ }^{31}$

Pengakuan "Rajaku dan Allahku" tidak hanya menggambarkan relasi pribadi pemazmur dan Allah tetapi juga menyatakan prioritas hidup pemazmur. Fokus hidup pemazmur 
tertuju hanya kepada Allah saja. Inilah yang menyebabkan pemazmur membenci apa dan siapa yang membenci Allah. Mereka ini memusuhi Allah dan akibatnya menjadi musuh pemazmur.

Motif Allah adalah Raja merupakan suatu motif penting dalam kitab mazmur. Sigmund Mowinckel bahkan memberi perhatian khusus terhadap motif ini dengan mengusulkan mazmur-mazmur Allah adalah Raja ditulis untuk keperluan festival penobatan raja (enthronement festival) saat hari raya Pondok Daun (Tabernacles). ${ }^{32}$ Festival penobatan raja merupakan festival merayakan "Yahweh's cosmic conflict, victory and enthronement". ${ }^{33}$ Namun bersama Routledge dan Weiser ${ }^{34}$ kita menyatakan bahwa PL tidak memberi informasi tentang keberadaan festival tersebut sebagai salah satu hari raya penting dalam kehidupan agama bangsa Israel. ${ }^{35}$ Lagi, memahami keragaman dan kekayaan latar kitab mazmur dalam satu festival penobatan raja merupakan upaya penafsiran reduktif. Lebih baik kita melihat mazmur-mazmur Allah adalah Raja menjadi motif penting ${ }^{36}$ terutama disebabkan keyakinan dasar bangsa Israel bahwa

32. Tentang Pondok Daun lihat Routledge, Old Testament Theology, 187.

33. Dikutip Routledge, Old Testament Theology, 227.

34. Weiser, Psalms, 62; Routledge, Old Testament Theology, 227.

35. Kritikan dan evaluasi terhadap teori Sigmund Mowinckel lihat J.J.M. Roberts, "Mowinckel's Enthronement Festival: A Review," dalam The Book of Psalms: Composition and Reception, ed. oleh Peter W. Flint dan Patrick D. Miller, Jr, Supplements to Vetus Testamentum XCIX (Leiden: Brill, 2005), 104-113.

36. Bila Eichrodt melihat perjanjian (covenant) dan Westermann mengusulkan penciptaan/keselamatan sebagai tema sentral PL, para ahli PL masa kini cenderung melihat kerajaan Allah sebagai tema sentral PL. 
Allah adalah Raja mereka yang menciptakan alam semesta dan segala isinya dan memilih mereka menjadi umat-Nya serta mengatur kehidupan mereka dengan hukum dan ketetapan-Nya. ${ }^{37}$ Keyakinan demikian diproklamirkan umat Israel sejak dini. Mereka membuat pengakuan Allah adalah Raja segera setelah mereka dibebaskan dari perbudakan Mesir (Kel. 15:18). Routledge menulis "he is King over Israel in a unique way, through divine election, and that special relationship is embodied within the covenant". ${ }^{38}$ Pengakuan Allah adalah Raja merupakan ekspresi dan wujud dari relasi personal Allah dan umat dalam ikatan perjanjian (covenant).

Mendengar seruan (ay. 4)

Allah yang disembah pemazmur adalah Allah yang hidup yaitu Allah yang mendengar seruan. la bukan Allah yang mati dan tuli tetapi Allah yang mendengar seruan pemazmur yakni perkataan, keluh kesah dan teriaknya minta tolong. Allah digambarkan pemazmur secara antropomorfis sebagai Allah yang mendengar. Keadaan mendesak ratapan pemazmur dinyatakan melalui penggunaan kata teriak (ay. 3), kata seruan (ay. 4) dan penggunaan dua kali ungkapan pagi hari (ay. 4). Pemazmur memiliki keyakinan kuat bahwa Allah mendengar seruannya. Keyakinan ini didasarkannya kepada

37 Tidak tepat pernyataan Anderson, Psalms 1-72, 1: 82, yang menyatakan bahwa pemazmur memahami istilah Rajaku sebagai "the supreme judge par excellence". Tafsiran Anderson ini berangkat dari asumsi bahwa pemazmur sedang menghadapi fitnah dari rekan sebangsanya.

38 Routledge, Old Testament Theology, 228; Juga Craigie, Psalms 1$50,86$. 
kenyataan hidupnya. Pemazmur tidak melakukan kejahatan, berkata bohong dan bukan penumpah darah dan penipu. Keadaan demikian merupakan bukti konkret bahwa pemazmur telah mengalami kasih setia Tuhan. Perbuatan baik pemazmur bukan untuk menggapai kasih setia Allah. Sebaliknya, perbuatan baiknya adalah bukti pemazmur telah mengalami kasih setia Allah dalam hidupnya.

Tidak berkenan kefasikan (ay. 5)

Kesejajaran kola ayat 5-7 memperlihatkan bahwa istilah kefasikan menunjuk kepada orang jahat, pembual, yang melakukan kejahatan, berkata bohong, penumpah darah dan penipu. Istilah orang jahat adalah terjemahan bahasa Ibrani yang merujuk kepada "persons arrogant and confident in their own strength". ${ }^{39}$ Istilah penumpah darah menunjuk kepada "persons whose falsehood and deceitfulness create trouble for the weak and innocent, and could in certain cases result in the death of the innocent (e.g. through false testimony in court)" ${ }^{40}$ Kelihatannya tampilan kefasikan dalam ayat 5 lebih menunjuk kepada perkataan ketimbang perbuatan. Perkataan jahat orang fasik tidak hanya merusak jiwa pendengarnya bahkan membunuhnya. Pengertian ini ditegaskan ayat 10. Kerongkongan seteru pemazmur digambarkan seperti kubur ternganga yang siap menerima mayat ke dalamnya. Perkataan seteru pemazmur membunuh. Senada, Goldingay menulis bahwa orang fasik adalah

39. Craigie, Psalms 1-50, 86.

40. Craigie, Psalms 1-50, 87. 
"people of murderous deceit, who use false accusation to defraud others of their land and thus their livelihood and, potentially, their lives". ${ }^{41}$

Sebab Engkau bukanlah Allah yang berkenan kepada kefasikan;

$\begin{array}{lll}\text { orang jahat } & \text { takkan menumpang } & \text { pada-Mu. } \\ \text { Pembual } & \text { tidak akan tahan } & \text { di depan mata-Mu; }\end{array}$

Engkau membenci semua orang yang Engkau membinasakan orang-orang yang TUHAN jijik melihat melakukan kejahatan. berkata bohong, penumpah darah dan penipu.

Allah yang dikenal pemazmur adalah Allah yang tidak berkenan kepada kefasikan. Orang fasik tidak tahan berdiri di depan kekudusan Allah apalagi menumpang pada Allah. Kata kerja menumpang (yügurkä) berarti "to leave one's homeland for political, economic, religious, or other circumstances and to dwell as a newcomer and resident alien without the original rights of the host community for a definite or indefinite time in order to find protection, a resting place, and a home in another community." 42 Pemazmur yang menumpang pada Allah menggambarkan ketergantungan hidup yang penuh pada Allah dan perlindungan total dari Allah terhadap hidup dan masa depannya. Sebaliknya orang jahat tidak menumpang karena Allah membenci kefasikan dan membinasakan orang fasik.

41. Goldingay, Psalms 1-41, 1: 129.

42. Waltke, Houston, dan Moore, Psalms as Christian Lament, 34. 
Sebaliknya, pemazmur berada di hadirat Allah bukan karena ia tidak sama dengan orang fasik. Pemazmur menggambarkan dirinya sebagai orang yang mengasihi nama Allah (ay. 12) dan orang benar (ay. 13). Akan tetapi bukan ini yang membawa pemazmur kehadirat Allah. Juga bukan perbuatan-perbuatan baik pemazmur yang menyebabkannya berada di hadapan Allah. Jika pemazmur menyatakan Allah berkenan kepadanya, itu semata-mata hanya oleh kasih setia Allah kepadanya. Tidak ada alasan lain.

Keadilan (ay. 9)

Seperti dijelaskan di atas, pemazmur memiliki seteru bukan karena mereka yang menyebabkan kerugian materi dan penganiayaan fisik terhadap pemazmur. Mereka menjadi musuh pemazmur oleh karena Allah tidak berkenan kepada perkataan dan perbuatan mereka. Pemazmur hidup dan berada di tengah-tengah orang fasik. Pemazmur tidak meminta Allah untuk menghukum mereka seperti pendapat Artur Weiser. Pemazmur memohon Allah agar menuntunnya di dalam keadilan Allah. Apa artinya? Pemazmur melihat perkataan dan perbuatan jahat orang fasik itu sendiri yang membawa hukuman terhadap mereka sendiri. Hukuman yang dialami orang fasik disebabkan oleh perkataan dan perbuatan jahat itu sendiri. Penggunaan bentuk Hiphil verba 'biarlah mereka

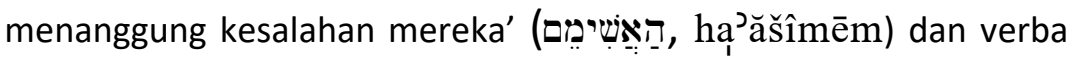

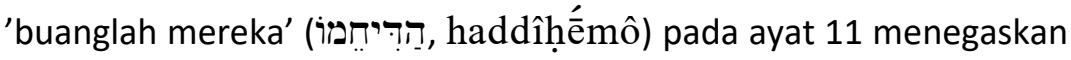
penghukuman diri sendiri. Menurut Ernst Jenni verba Hiphil 
digunakan untuk menggambarkan keadaan "to cause an event" ${ }^{43}$ Keadaan kausatif verba haddîhếmô menggambarkan keadaan orang fasik yang terbuang oleh karena pelanggaran mereka sendiri. Orang fasik jatuh karena rancangan mereka sendiri. Ungkapan 'biarlah mereka jatuh' pada ayat 11 merupakan metafora "violent death". ${ }^{44}$ Hukuman paling dahsyat terhadap manusia adalah dibuang dari hadirat Allah. Seperti umat pilihan Allah bangsa Israel, puncak hukuman terhadap mereka adalah pembuangan. Mereka dibuang ke Babel jauh dari hadirat Allah yang disimbolkan dengan bait Allah di Yerusalem.

Keadilan Allah dalam Mazmur 5 menunjuk kepada hukuman yang terjadi terhadap diri sendiri oleh karena perbuatan dan perkataan jahat sendiri. Hukuman terjadi karena perbuatan dan perkataan jahat dipandang sebagai pemberontakan terhadap Tuhan Allah. Berdasarkan pengertian ini tidak tepat Barth-Frommel dan Pareira merumuskan keadilan Allah sebagai "Jalan karya keselamatan yang datang dari Tuhan". ${ }^{45}$

Pemazmur hidup di tengah-tengah orang fasik. Perkataan mereka membunuh. Kerusakan sosial yang ditimbulkan orang fasik sedemikian hebat. Mereka seolah hidup tanpa hukuman terhadap perkataan jahat yang diucapkan. Apakah mereka bebas dari

43 Dikutip Michael Patrick O'Connor dan Bruce K. Waltke, Introduction to Biblical Hebrew Syntax (Winona Lake: Eisenbrauns, 2004), 433.

44. Waltke, Houston, dan Moore, Psalms as Christian Lament, 39.

45. Barth-Frommel dan Pareira, Mazmur 1-72, 152. 
hukuman? Pemazmur menjawab tegas 'tidak!'. Keadilan Allah akan berlaku atas mereka. Keadilan Allah dipandang sebagai hukuman terhadap diri sendiri disebabkan perbuatan dan perkataan sendiri.

Tempat berlindung (ay. 12)

Pemazmur berlindung pada Tuhan. Peristiwa ini membuatnya bersukacita (ay. 12). Kesejajaran 4 kola ayat 12-13 menampilkan alasan mengapa pemazmur bersukacita. Pemazmur bersukacita oleh karena Allah menaungi, memberkati dan memagarinya.

karena Engkau menaungi mereka; dan karena Engkau akan bersukaria orang-orang yang mengasihi nama-Mu. Sebab Engkaulah yangmemberkati orang benar, ya TUHAN; Engkau memagari dia dengan anugerah-Mu seperti perisai.

Allah menaungi (woțāsēḳ) mereka yang mengasihi nama Yahweh. Ungkapan Allah menaungi merupakan gambaran seperti induk ayam atau burung yang mengembangkan sayapnya menutupi anak-anaknya yang berada di bawah sayapnya (Mzm. 91:4).

Seperti dijelaskan di atas, berlindung pada Allah berarti berada di bait Allah di Yerusalem untuk sujud menyembah-Nya. Pemazmur beribadah di bait suci bersama dengan para umat. Ibadah pemazmur dipenuhi dengan sukacita oleh karena fungsi teofani nama Yahweh (ay. 12). Nama Yahweh menyatakan bahwa "God is eternal and that 
he must define his mystery by revealing himself in interpreted historical acts and by proposional statements." 46

Keberadaan pemazmur dan seterunya digambarkan ayat 1012 dalam tiga kontras sebagai berikut:

(1). The wicked fall to their own demise (ay. 11), but the righteous find refuge in God (ay. 12).

(2). The speech of the wicked is deadly and deceitful (ay. 10), but the righteous sing for joy (ay. 12).

(3). The wicked are banished from God (ay. 11), but God shelters the righteous. ${ }^{47}$

Perbandingan kontras pemazmur dan seteru merupakan gambaran perlindungan hidup pemazmur.

Tidak hanya terlindung, pemazmur dinyatakan juga sebagai orang benar (ay. 13). Orang benar merujuk kepada "those who love to bring about right and harmony for all by submitting themselves to the Law/Word (Logos) of God". ${ }^{48}$

\section{Perubahan Suasana Teks (Mood)}

Bagian penutup Mazmur 5 pada ayat 13 berakhir dengan teks bersuasana pujian. Suasana pujian ini menyingkapkan bahwa Allah mendengar keluhan pemazmur. Kesadaran pemazmur 'Allah mendengar seruan' mengubah suasana teks dari ratapan (ay. 2-3)

46. Waltke, Houston, dan Moore, Psalms as Christian Lament, 30.

47. Waltke, Houston, dan Moore, Psalms as Christian Lament, 40.

48. Waltke, Houston, dan Moore, Psalms as Christian Lament, 41. 
menjadi suasana pujian (ay. 4-8). Namun suasana teks berubah menjadi ratapan pada ayat 9-11 di mana pemazmur mengenal keadilan Allah (ay. 9). Sejalan dengan perasaan sukacita pemazmur yang muncul karena pemazmur berlindung pada Allah (ay. 12) suasana teks berganti menjadi pujian (ay. 12-13). Penggambaran grafis di bawah ini memperlihatkan pengenalan Allah sebagai Allah yang mendengar seruan (ay. 4) dan Allah tempat berlindung (ay. 12) mengubah suasana teks dari ratapan menjadi pujian. Pengenalan pemazmur terhadap Allah mengubah ratapannya menjadi pujian. Pemazmur menjalani pergumulan rohaninya, seperti digambarkan grafis, dalam suasana positif. Pujian mendominasi hidup pemazmur menjalani hidup di tengah-tengah pergumulan rohani.

$\begin{array}{llllllllllll}2 & 3 & 4 & 5 & 6 & 7 & 8 & 9 & 10 & 11 & 12 & 13\end{array}$

\begin{tabular}{|l|l|l|l|l|l|l|l|l|l|l|l|}
\hline & & & & & & & & & & & \\
\hline & & & & & & & & & & & \\
\hline & & & & & & & & & & & \\
\hline & & & & & & & & & & & \\
\hline
\end{tabular}

Melihat penggambaran grafis tersebut di atas terungkap suatu struktur komposisi mazmur 5 yang berbeda dengan usulan struktur komposisi penafsir-penafsir mazmur selama ini. ${ }^{49}$

49. Lihat, misalnya, Waltke, Houston, dan Moore, Psalms as Christian Lament, 26-27. 
Superskrip (ay. 1)

Ratapan (ay. 2-3)

Pujian (ay. 4-8)

Ratapan (ay. 9-11)

Pujian (ay. 12-13)

\section{Renungan}

Pemazmur hidup dikelilingi oleh orang fasik. Tidak ada yang dapat diperbuatnya terhadap mereka. Pemazmur tidak mampu dan tidak berdaya menghentikan perkataan dan perbuatan jahat mereka. Pemazmur juga tidak berniat meninggalkan lingkungan di mana ia berada Apa yang menyebabkan pemazmur bertahan hidup dalam lingkungan fasik seperti itu? Jawabannya? Dua tindakan pemazmur tampak melalui Mazmur 5 sebagai berikut.

\section{Ibadah}

Perkataan dan perbuatan orang fasik mengepung hidup pemazmur. Tidak sanggup pemazmur melawan mereka. Yang dilakukan pemazmur adalah berlindung kepada Allah saja. Allah memagarinya. Pemazmur terlindung berada di bait Allah. Akan tetapi tidak berarti pemazmur melarikan diri dari kenyataan hidup dan tidak berani menghadapi mereka. Apakah ibadah di bait Allah menjadi tempat pelarian pemazmur? Tidak. Pemazmur tidak melarikan diri dari lingkungannya. Jika pemazmur berada di bait Allah, itu dirasakan dan dialami pemazmur hanya karena kasih setia Allah saja. Perbuatan dan perkataan pemazmur yang tidak mengikut cara hidup orang fasik 
disebabkan kasih setia Allah saja. Ini juga tidak berarti pemazmur hidup tanpa dosa. Pemazmur bergumul dalam ketegangan berjalan sebagai orang benar di tengah-tengah kehidupan orang fasik. Di tengah ketegangan itu ibadah menjadi sumber kekuatan pemazmur.

Ibadah adalah respons terhadap Allah. Pertama, ibadah adalah respons terhadap pendamaian. Allah menetapkan di mana, kapan dan bagaimana la harus disembah umat. Ibadah terjadi secara komunal pada tempat yang ditetapkan Allah yakni di bait Allah di Yerusalem. Pada zaman PL umat datang ke bait Allah untuk mempersembahkan korban sebagai pengganti hidupnya. Gagasan penggantian ini dijelaskan sebagai berikut: "shedding blood signifies death, and the death of the animal, on behalf of the sinner or sinful community, opens the way for cleansing and forgiveness, and for God's continued presence among his people". ${ }^{50}$ Tanpa pencurahan darah tidak ada pengampunan (Ibr. 9:22). Gagasan penggantian itu esensinya menunjuk ke masa depan kepada zaman PB. Pendamaian dengan Allah terjadi oleh karena darah Yesus menggantikan hidup manusia yang percaya kepada-Nya. Hanya mereka yang telah berdamai dengan Allah melalui Yesus Kristus dapat mendekati Allah dalam ibadah. Pendamaian manusia berdosa dengan Allah di dalam dan melalui Yesus Kristus merupakan titik berangkat ibadah.

Ibadah kemudian berlanjut sebagai respons terhadap penyingkapan Allah. Pendamaian manusia kepada Allah membawanya kepada penyingkapan Allah. Manusia melihat melihat

50. Routledge, Old Testament Theology, 195. 
kemuliaan Allah di bait Allah di Yerusalem. Sekarang manusia yang telah berdamai dengan Allah melihat kemuliaan Allah melalui dan di dalam persekutuan jemaat sebagai tubuh Kristus. Di dalam persekutuan jemaat Allah berbicara kepada jemaat melalui dan di dalam Alkitab.

Jadi, dua unsur utama dalam ibadah adalah pengampunan dosa dan penyingkapan diri Allah melalui pemberitaan Firman Tuhan.

Bagaimana ibadah di Indonesia? Ibadah di Indonesia pada umumnya dibangun di atas pengertian Yohanes 4:23-24 "menyembah Allah dalam roh dan kebenaran". Kata roh ditafsirkan sebagai roh manusia. Oleh karena itu, beribadah berarti membawa dan mengangkat roh manusia ke hadirat Allah. Ketika itulah manusia menyembah Allah. Bagaimana caranya membawa dan mengangkat roh manusia? Dengan musik. Musik yang dimainkan oleh pemusik profesional dipandang sebagai hal sentral dalam ibadah. Musik mampu membawa roh manusia ke hadirat Allah. Tidak heran bila banyak gereja tidak sungkan menaruh investasi besar untuk membeli peralatan musik termasuk membayar mahal pemusik profesional. Namun musik saja dipandang belum cukup, perlu seorang atau beberapa pemimpin ibadah atau sering dikenal dengan sebutan WL yang merupakan singkatan dari worship leader. Sang pemimpin ibadah ini bertugas untuk memastikan bahwa roh manusia yang beribadah saat itu telah berada di hadirat Allah. Meski ibadah masih dipandang sebagai perjumpaan dengan Allah, ibadah seperti ini keliru. Mengapa? Jemaat beribadah kepada Allah menurut cara dan 
usaha manusia bukan seperti yang dikehendaki Allah. Kata roh dalam Yohanes 4:23-24 tidak dapat ditafsirkan sebagai roh manusia. Kata roh dalam ayat itu merujuk kepada Roh Kudus. ${ }^{51}$ Hanya dengan pertolongan dan di dalam persekutuan dengan Roh Kudus manusia dapat menyembah Allah. Bila kata roh diartikan sebagai roh manusia, ibadah berpusat pada manusia. Fokus ibadah terarah sepenuhnya kepada roh manusia, tidak lagi kepada Allah. Kendali ibadah berada di tangan pemimpin ibadah, bukan pada Roh Kudus. Lagi, ibadah yang demikian kelihatannya tak ubahnya seperti konser musik. Musik menggantikan dimensi pengakuan dan pengampunan dosa dalam ibadah.

\section{Hidup dalam keadilan Tuhan}

Perkataan dan perbuatan jahat orang fasik dalam dirinya sendiri telah mengandung hukuman. Orang fasik mengundang hukuman terhadap diri sendiri melalui perkataan dan perbuatan jahat yang mereka rancangkan. Sebaliknya pemazmur hidup sebagai orang benar. Pemazmur hidup dalam keadilan Tuhan. Artinya? Hukum Tuhan, seperti pengakuan pemazmur bahwa Allah adalah Rajaku, menjadi tuntunan hidupnya. Hukum Tuhan esensinya mencerminkan karakter Allah. Dengan demikian perkataan dan perbuatan pemazmur

51. C.K. Barrett, The Gospel according to St John: An Introduction with Commentary and Notes on the Greek Text, 2 ed. (London: SPCK, 1978), 238239; Herman N. Ridderbos, The Gospel according to John: A Theological Commentary (Grand Rapids, Michigan: William B. Eerdmans, 1997), 163164. 
mencerminkan karakter Allah. Pemazmur mengundang orang fasik, yang menjadi seterunya, untuk mengenal Allah melalui perkataan dan perbuatannya yang mencerminkan karakter Allah. Relasi pemazmur dengan manusia di sekelilingnya yang hidup dalam kefasikan merupakan wujud pengenalan pemazmur akan Allah.

\section{Kepustakaan}

Anderson, A.A. The Book of Psalms: Psalms 1-72. Vol. 1. New Century Bible Commentary. Grand Rapids, Michigan: William B. Eerdmans, 1972.

Barrett, C.K. The Gospel according to St John: An Introduction with Commentary and Notes on the Greek Text. 2 ed. London: SPCK, 1978.

Barth-Frommel, Marie-Claire, dan B. A. Pareira. Kitab Mazmur 1-72:

Pembimbing dan Tafsirannya. Jakarta: BPK Gunung Mulia, 2012.

Barus, Armand. Mengenal Tuhan Melalui Penderitaan. Jakarta: Scripture Union Indonesia, 2016. "Menghadapi Kebohongan: Penelitian Puitis Mazmur 4." Amanat Agung 14, no. 1 (Juni 2018): 1-24. . "Sembuhkanlah Aku: Penelitian Puitis Mazmur 6." Amanat Agung 12, no. 2 (Desember 2016): 175-206.

Blocher, Henri. "The fear of the Lord as the "principle" of wisdom." Tyndale Bulletin 28 (1977): 3-28.

Broyles, Craig C. "Psalms Concerning the Liturgies of Temple Entry." Dalam The Book of Psalms: Composition and Reception, disunting oleh Peter W. Flint dan Patrick D. Miller, Jr, 248287. Leiden: Brill, 2005.

Craigie, Peter C. Psalms 1-50. Word Biblical Commentary 19. Dallas: Word Books, 1983.

Davidson, Robert. The Vitality of Worship: A Commentary on the Book of Psalms. Grand Rapids, Michigan: William B. Eerdmans, 1998. 
Dyrness, William. Themes in Old Testament Theology. Downers Grove: IVP Press, 1979.

Eichrodt, Walther. Theology of the Old Testament. Vol. 1. Philadelphia: Westminster, 1961. . Theology of the Old Testament. Vol. 2. Philadelphia: Westminster, 1967.

Goldingay, John. Psalms 1-41. Vol. 1. Baker Commentary on the Old Testament Wisdom and Psalms. Grand Rapids: Baker Academic, 2006.

. Psalms 90-150. Vol. 3. Baker Commentary on the Old Testament Wisdom and Psalms. Grand Rapids, Michigan: Baker Academic, 2008.

Keel, Othmar. The Symbolism of the Biblical World: Ancient Near Eastern Iconography and the Book of Psalms. Winona Lake: Eisenbrauns, 1997.

Lee, Sung-Hun. "Lament and the Joy of Salvation in the Lament Psalms." Dalam The Book of Psalms: Composition and Reception, disunting oleh Peter W. Flint dan Patrick D. Miller, Jr, 224-247. Supplements to Vetus Testamentum XCIX. Leiden: Brill, 2005.

O'Connor, Michael Patrick, dan Bruce K. Waltke. Introduction to Biblical Hebrew Syntax. Winona Lake: Eisenbrauns, 2004.

Ridderbos, Herman N. The Gospel according to John: A Theological Commentary. Grand Rapids, Michigan: William B. Eerdmans, 1997.

Roberts, J.J.M. "Mowinckel's Enthronement Festival: A Review." Dalam The Book of Psalms: Composition and Reception, disunting oleh Peter W. Flint dan Patrick D. Miller, Jr, 97-115. Supplements to Vetus Testamentum XCIX. Leiden: Brill, 2005. Routledge, Robin. Old Testament Theology: A Thematic Approach. Downers Grove: IVP Academic, 2008.

Schwab, Zoltàn. "Is Fear of the LORD the Source of Wisdom or Vice Versa?" Vetus Testamentum 63, no. 4 (Oktober 2013): 652662.

Villanueva, Federico G. The 'Uncertainty of a Hearing': A Study of the Sudden Change of Mood in the Psalms of Lament. Supplements to Vetus Testamentum 121. Leiden: Brill, 2008. 
Waltke, Bruce K., James M. Houston, dan Erika Moore. The Psalms as Christian Lament: A Historical Commentary. Grand Rapids, Michigan: William B. Eerdmans, 2014.

Weiser, Artur. The Psalms: A Commentary. The Old Testament Library. Philadelphia: Westminster, 1962. 